\title{
POLSKA STRAŻ GRANICZNA - ROZPOZNAWANIE I PRZECIWDZIALANIE ZAGROŻENIOM TERRORYZMEM W KONTEKŚCIE PRAWODAWSTWA POLSKIEGO I EUROPEJSKIEGO
}

Rozpoznanie, jakie w zakresie terroryzmu prowadzą podmioty państwowe, w tym rozpoznanie i przeciwdziałanie realizowane przez wyspecjalizowane struktury ${ }^{1}$ Straży Granicznej wskazuje, że podjęcie na terytorium Rzeczypospolitej Polskiej bezpośredniego, zbrojnego działania o charakterze terrorystycznym, jest nadal potencjalnie niskie. Sytuacja ta pozostaje jednak dynamiczną i może ulec zmianie, w krótkim okresie ${ }^{2}$,

1 W Straży Granicznej (SG), w związku z nowelą ustawy kompetencyjnej, po dokonaniu stosownych zmian reorganizacyjnych, począwszy od roku 2006, rozpoczął się proces tworzenia w ówczesnych Wydziałach Operacyjno-Śledczych (WOŚ) oddziałów SG sekcji/zespołów do spraw rozpoznawania zagrożeń terrorystycznych. Ich skład ustalany jest precyzyjnie - w zależności od specyficznych potrzeb służby. W Placówkach SG (odpowiednik połączonej komendy rejonowej i komisariatu Policji) za realizację tego rodzaju czynności odpowiadają wyznaczeni funkcjonariusze, merytoryczni podlegli pod wyżej wymienione Wydziały Operacyjno-Śledcze Oddziałów Straży Granicznej. Za nadzór nad czynnościami podejmowanymi przez całość wyżej wymienionej struktury odpowiadał Zespół do spraw Monitoringu Zagrożeń Terroryzmem Zarządu Operacyjno-Śledczego Komendy Głównej Straży Granicznej (ZMZT ZOŚ KGSG), a następnie Sekcja Monitoringu Zagrożeń Terrorystycznych ZOŚ KGSG.

2 Rozpoznawanie zagrożeń terroryzmem musi pozostawać w ścisłej korelacji z globalnym rozpoznaniem zagrożeń terroryzmem na świecie. Wpływ na powyższe ma niezwykle dużo czynników społecznych, geopolitycznych i innych, które winny być stale monitorowane przez właściwe służby i instytucje (AW, ABW, SWW, SKW, MSZ, MON, BBN, Policja, RCB, MF, BOR, SG i inne w zależności od okoliczności). Polska pozostaje do tej pory wyspa jedynie na mapach wzrostu gospodarczego w okresie globalnego kryzysu oraz raportach Europolu o zarejestrowanych zamachach terrorystycznych lub powiązanych z nimi osobach zatrzymanych. Nie jest natomiast wyspą w działaniach grup terrorystycznych, tak jak nie jest wyspą w ramach gier wywiadów, które identyfikowane są m.in. przez pion kontrwywiadu $\mathrm{ABW}$, w polach oczywistej działalności siatek agenturalnych tworzonych przez rezydentów - częstokroć poruszających się w ramach przedstawicielstw dyplomatycznych, przedstawicielstw handlowych, zagranicznych dziennikarzy itp., wykonujących na terenie RP bieżące aktywne posunięcia, akcje pozorowane, $\mathrm{i}$ inne $\mathrm{w}$ ramach własnych projektów wywiadowczych - głównie w ramach przenikania agenturalnego. Praca wywiadu i kontrwywiadu, ale również praca w zakresie zwalczania terroryzmu może być realizowana skutecznie jedynie pod pełnym przykryciem (tj. zabezpieczeniem, konspiracją), również bez rozgłosu medialnego. Ma to jednak swoją cenę. Częstokroć brak informacji w społeczeństwie przyczynia się do braku akceptacji działań służb budujących nowe struktury w ramach przeciwdziałania zjawisku. To z kolei, czego przykładem może być np. Wielka Brytania, skłania do funkcjonowania wywiadów pod głęboką konspiracją. Tego rodzaju przykrycie częstokroć jest niezbędne do stosowania w warsztacie służb, np. skrytych rewizji (w państwach demokratycznych wymagalna zgoda organów sądowych) specyficznych czynności, których opisu autor podjął się w innym materiale, w formule przystępnej do zakresu jawnego. Wewnętrzne, 
tym bardziej, że pojawiają się pogróżki składane pod adresem Polski przez fundamentalistów islamskich, wskazujących RP jako jednego z żotnierzy armii wroga.

Należy przyjąć, iż przeprowadzenie obecnie bezpośredniego ataku terrorystycznego w Polsce jest na najniższym, pierwszym katalogowanym poziomie. Może być to spowodowane wieloma czynnikami, z których na szczególną uwagę zasługują następujące:

1. Stosunkowo mała ilość cudzoziemców wyznających islam, którzy zamieszkują w Polsce ${ }^{3}$, wśród nich mała ilość osób zradykalizowanych (kwestia ta zaprezentowana zostanie w dalszej części).

2. Mała ilość wyznawców islamu wśród cudzoziemców pochodzących z państw objętych działaniami militarnymi w ramach tzw. koalicji antyterrorystycznej ${ }^{4}$ oraz działaniami Federacji Rosyjskiej, ChRL, Izraela.

3. Znaczny odsetek z grupy osób, które wymieniono w pkt 1 , to od pokoleń mieszkańcy i obywatele Polski, nie budzący większych zastrzeżeń służb ${ }^{5}$.

4. Cudzoziemcy, którzy przybyli do RP z obszarów objętych działaniami militarnymi, to głównie obywatele Rosji narodowości czeczeńskiej ${ }^{6}$, przyjęci w Polsce jako uchodźcy (lub korzystający ze statusu humanitarnego) i w znacznej mierze zaopatrywani w środki do życia ${ }^{7}$. Pozytywny stosunek tych osób do Polski, jak się przewiduje, $\mathrm{z}$ biegiem czasu będzie słabnąć. Ową zależność pogłębiać będą trudności w asymilacji, w szczególności II oraz III pokolenia.

5. Polska traktowana jest przez liderów światowego terroryzmu jako tzw. cel zapasowy, jednakże z tendencją wzrostową ${ }^{8}$. Czynnikiem aktywizującym działalność grup

rodzime grupy ekstremistyczne, na chwilę obecną, jak się wydaje, nie decydują się na działania terrorystyczne, choć stosowane przez nie metody zapewne niejednokrotnie winny skłaniać do rozważenia wobec nich aplikowania procedur karnych określonych, m.in. w art. 190 Kodeksu karnego, tzw. groźby karalne.

${ }^{3}$ Około 0,05\% społeczeństwa (38 mln osób zamieszkałych w RP), podczas gdy np. w RFN odsetek ten stanowi ok. 4\% społeczeństwa (ok. $80 \mathrm{mln}$ ludzi zamieszkałych). Z badań autora zleconych przez ministra A. Rapackiego, Stopień radykalizacji w RP, Straż Graniczna, Warszawa 2011.

4 Oczywiście największa grupa cudzoziemców z tego rodzaju regionów to Czeczeni (szczegóły zostaną przedstawione w dalszej części).

5 W Polsce najaktywniejszymi organizacjami skupiającymi muzułmanów (prócz innych pomniejszych) pozostają: Liga Muzułmańska oraz Muzułmański Związek Religijny, konkurujące za sobą w ramach prymatu nad przewodnictwem muzułmanom zamieszkałym w RP.

6 Jest rzeczą charakterystyczną, że w Europie Zachodniej nie dokonuje się przedstawionego podziału, który znany jest w Polsce. Należy dodać, że w związku z brakiem uznania Czeczenii przez społeczność międzynarodową za suwerenne państwo, zamieszkali tam obywatele, posiadają rosyjskie paszporty).

7 W ostatnich latach do ośrodków dla uchodźców trafiają w zdecydowanej większości uchodźcy z Kaukazu Północnego. Warty wskazania jest fakt, iż w związku z polityką UE w zakresie uchodźców Polska otrzymuje z unijnego budżetu środki na utrzymanie wyżej wymienionych ośrodków.

${ }^{8}$ Wydaje się, że możliwość dokonania zamachu terrorystycznego w RP, przy zachowaniu obecnie funkcjonujących czynników zagrożenia, o których mowa jest w artykule, możliwa jest w szczególności w przypadku dalszego angażowania się państwa w przedsięwzięcia koalicji antyterrorystycznej, jak również z udziałem społeczności czeczeńskiej, np. przy modelowaniu jej przez służby specjalne jednego z państw trzecich. Czynnikiem, nabierającym coraz większego znaczenia jest działalność grup skrajnie prawicowych. Będą to jednak najprawdopodobniej zamachy terrorystyczne podjęte przez grupy spoza grona zarządczego funkcjonujących organizacji tetrystycznych i innych połączonych ideologicznie np. z Al-Kaida, wykonane przez sfrustrowanych, uniezależniających się 
terrorystycznych jest głównie polityka państwa polskiego, o czym szerzej w dalszej części. Cel zapasowy oznacza, że Polska jest dla terrorystów państwem o stosunkowo małym znaczeniu w zakresie możliwości propagandowych (w przypadku spowodowania zdarzenia o charakterze terrorystycznym). Ponadto, posiadając mimo wszystko ograniczone zasoby, terroryści atakują główne ośrodki demokratycznego świata, który w ich ocenie wypowiedział im wojnę. Jednocześnie istnieje ryzyko przeniesienia działań zbrojnych na terytorium RP w aspekcie coraz sprawniejszego systemu kontrterrorystycznego krajów Europy Zachodniej;

6. Na terytorium Polski oficjalnie nie odnotowano zatrzymań terrorystów lub osób z nimi powiązanych ${ }^{9}$. Podkreślić należy, że istnieje prawny obowiązek informowania organów UE o ujawnieniu, zatrzymaniu takich osób ${ }^{10}$. Wobec tego skłaniać się można ku teorii o potencjalnej możliwości wykorzystywania RP jako bazy do odpoczynku, zbierania funduszy oraz zakładania siatek logistycznego wsparcia dla grup terrorystycznych.

Ustalenie czynników warunkujących skuteczność działan terrorystycznych jest ważne do opracowywania metod ich zwalczania. Czynniki te przedstawiają się następująco:

a) skuteczność osiagania celów w wyniku stosowania terroru, szczególnie przy nieświadomie współdziałających mediach ${ }^{11}$;

b) uczestnictwo w koalicji antyterrorystycznej oraz misjach stabilizacyjnych ${ }^{12}$;

członków. To typowa strategia części przestępczości zorganizowanej (terroryzm jest jej odmiana), której członkowie usiłują wymknąć się spod kurateli swoich zwierzchników, wybijając się na liderów niezadowolonej mniejszości. W pracy wyjaśniona zostaje przychylność, nazwijmy to, dowództwa terrorystów do traktowania terytorium RP jako spokojnej przystani, w celu logistycznego funkcjonowania wymienionych wyżej grup. Oczywiste jest, iż Polska takim państwem pozostaje. Jako członek grupy Schengen jest idealnym tego typu miejscem. Ponadto, spowodowanie w Polsce działań o charakterze terrorystycznym, przyczyni się do jednej z najgorszych dla terrorystów rzeczy, mianowicie spowoduje przyśpieszenie implementacji rozwiązań krajów doświadczonych tego typu zamachami, częstokroć spotykającą się z naturalną niechęcią z uwagi na fakt zwiększania uprawnień służb policyjnych oraz specjalnych. W tego typu wyzwaniach niezbędne jest prowadzenie rozpoznania operacyjnego oraz sprawnej pracy z wykorzystaniem narzędzi śledzenia finansów potencjalnych grup $\mathrm{i}$ jednostek terrorystycznych.

9 Obserwowane są natomiast przejazdy, lub krótkotrwałe pobyty osób mogących mieć takie powiązania.

10 Decyzja Rady UE z 20 września 2005 roku w sprawie wymiany informacji i wspótpracy dotyczacej przestepstw terrorystycznych, Dz. U. UE L 2005, nr 253, poz. 22.

${ }_{11}$ Niezbędna w powyższym zakresie jest właściwa, precyzyjnie określona polityka medialna państwa. Społeczeństwo kształtuje swoje poglądy i postawy w znacznej mierze na podstawie informacji przekazywanych przez media, których przedstawiciele, szczególnie młodzi dziennikarze ,goniący" za sensacją, nie mają najczęściej świadomości zagrożeń wynikających z przekazywanych przez siebie informacji (wnioski pokonferencyjne z roku 2008/2009 w ramach przedsięwzięcia Biura Bezpieczeństwa Narodowego w rzeczonym zakresie wypowiadane m.in. przez byłego redaktora naczelnego tygodnika „Wprost” oraz przedstawicieli TVP.

12 Buduje to potencjał radykałów islamskich do klasyfikowania RP jako kolejnego celu w ramach tzw. świętej wojny. Ponadto wprost przekłada się m.in. na zagrożenie placówek, interesów Polski, jak $\mathrm{i}$ ich obywateli w tzw. państwach podwyższonego ryzyka. Najjaskrawszym przykładem ostatnich miesięcy, choć nie jedynym atakiem na niżej wymienione przedsiębiorstwo, które ze względu na spodziewane zyski nie zakończyło prac w różnych częściach świata, jest zabójstwo w 2009 roku pracownika Geofizyki Kraków Piotra Stańczaka. Istotna jest również świadomość, iż pomimo walk 
c) bliskie stosunki z USA (wymieniane np. w 167-stronicowej strategii antyterrorystycznej Wielkiej Brytanii Contest II, będącej wzorem do opracowania polskiego Narodowego Programu Antyterrorystycznego), w tym również przynależność do NATO;

d) powtarzane informacje medialne na temat funkcjonowania w Polsce tajnych więzień CIA ${ }^{13}$ (słusznym jest jednomyślność polskich władz w prezentowaniu stanowiska w tej sprawie);

e) przynależność do strefy Schengen ${ }^{14}$, która w 2012 roku najprawdopodobniej rozszerzy się o Bułgarię oraz Rumunię, powodując wzmocnienie istniejących i budowanie nowych kanałów nielegalnej migracji;

f) wzrost liczby wyizolowanych ze społeczeństwa, przeważnie słabo wykształconych i tworzących klany cudzoziemców (szczególnie dotyczy to obywateli terytoriów objętych działaniami wojennymi), którzy są podatni na działalność rodzimych grup przestępczych oraz radykałów islamskich. Po oszacowaniu zjawiska, należy rozważyć podjęcie w Polsce kroków zmierzających do nawiązania współdziałania w ramach tzw. europejskiej sieci ekspertów do spraw radykalizmu, która powstała w 2009 roku. Sieć powołano w celu wypełnienia strategii UE w tym zakresie. Obejmuje ona ekspertów z następujących dziedzin: media i komunikacja strategiczna (UK); szkolenie imamów (ES); działania policji na szczeblu lokalnym (BE); współpracę z władzami lokalnymi (NL); łagodzenie radykalizacji postaw (DK); oraz terroryzm w Internecie (DE). W Polsce brakuje tego typu rozwiązań.

7. Stałe docieranie do polskiej społeczności muzułmańskiej przedstawicieli ortodoksyjnych organizacji islamskich, niejednokrotnie identyfikowanych jako sympatyzujące z ugrupowaniami ekstremistycznymi. Można zadać pytanie, czy państwo ma

w Afganistanie (uznawanych przez dużą część ortodoksyjnego społeczeństwa za okupację) działania te nie wygasają. Dla porównania zaangażowanego w tym kraju potencjału wojennego (inaczej stabilizacyjnego) można przytoczyć pewne liczby. W czasach największego nasilenia działań wojsk radzieckich w Afganistanie stacjonowało tam ok. 110-120 tys. żołnierzy. Obecna liczba wojsk koalicji wynosi już przeszło 150 tys. i stale się zwiększa, również ze strony Polski. Jednak, faktem jest, że wojna ta rozprzestrzenia się również $\mathrm{w}$ formule tzw. walki o dusze przez rozprzestrzenianie ideologii (m.in. fatwy) przekazywanej za pośrednictwem Internetu, przez uczonych w Koranie oraz zaangażowanych w walki, nawołujących nie tylko do wstrzymania przyjazdów do Afganistanu kolejnych bojowników, terrorystów, których jest ponoć wystarczająca ilość, ale także do wypowiedzenia wojny światowi Zachodu przez działania w kraju zamieszkania każdego z muzułmanów. Przykładem takich działań mają być tzw. strategie samotnego wilka, ujawniające się pojedynczymi, aczkolwiek skutecznymi atakami w tkankę miękką poszczególnych państw (za dobry przykład może posłużyć atak w USA z 2010 roku amerykańskiego żołnierza - psychologa wojskowego, motywowanego ideologią dżihadu za pośrednictwem Internetu, który w jednostce zastrzelił kilkanaście osób zanim sam poniósł śmierć z ręki własnego kolegi). Do omówienia pozostaje jeszcze jedna kwestia. W dyskusjach mniej doświadczonych widzów teatru działań terrorystycznych, pojawiają się opinie, iż potencjalny terrorysta to jednostka niewykształcona o ograniczonym intelekcie. Jak można było się wielokrotnie przekonać, zamachów podejmują się ludzie wykształceni i postrzegani we własnych społecznościach jako spokojni, świetni fachowcy (np. w 2010 roku na terenie lotniska w Wielkiej Brytanii zamachu dokonał obywatel brytyjski pochodzenia pakistańskiego).

13 W czerwcu 2006 roku, organ ustanowiony przez Parlament Rady Europy stwierdził, iż w latach 2003-2005 w Polsce i Rumunii, funkcjonowały tajne więzienia Centralnej Agencji Wywiadowczej Stanów Zjednoczonych. Brak precyzyjnych danych co do liczby osób przetrzymywanych.

14 Dotyczy nieskrępowanego (brak kontroli) przekraczania granicy RP w ramach grupy państw tzw. układu z Schengen. 
interes w kreowaniu postaw pro-demokratycznych, wśród wyżej wymienionej grup? Czy będąc w stanie zagrożenia (a tak postrzegana jest obecna rzeczywistość przez zradykalizowanych członków wyżej wymienionej wspólnoty religijnej) będą oni popierać rozwiązania pokojowe czy też podejmą działania ekstremistyczne, popierając dżihad? W Polsce, oprócz programów asymilacyjnych, które (jak wykazuje praktyka) nie zawsze spotykają się z przychylnością cudzoziemców, do których są kierowane oraz nie są skuteczne (m.in. z powodu małych środków na ich prowadzenie), winno budować się specjalne programy dialogu międzykulturowego i międzyreligijnego. Należy wspierać uruchamianie nowych kierunków studiów dotyczących teologii islamu. Przykładem mogą być programy ministerstw edukacji Holandii oraz Niemiec. Jest jednak niezwykle istotne, by programy takie współtworzyli przedstawiciele wspólnot muzułmańskich. Jak pokazuje niemiecki przykład sprzed kilku lat, bez takiego podejścia trudno będzie osiągnąc jakiekolwiek zadowalające wyniki.

8. Możliwe instrumentalne wykorzystanie przebywających w Polsce osób narodowości czeczeńskiej do przeprowadzenia zamachu na terytorium Polski ${ }^{15}$.

9. Konwersja, a w tym wypaczone postrzeganie islamu ${ }^{16}$.

10. Możliwość radykalizacji zachowań osadzonych, którzy przebywają z więźnia$\mathrm{mi}$ - wyznawcami islamu, wykorzystującymi motywy religijne i ekstremistyczne ${ }^{17}$.

Rola Straży Granicznej (dalej: SG) w zakresie ujawniania i zwalczania ww. zagrożeń jest różnoraka. Straż Graniczna jest służbą będącą głównym filarem polskiego systemu zwalczania nielegalnej migracji. Formacja przeznaczona jest do walki z tzw. przestępczością graniczną (transgraniczną) i wykorzystuje wszelkie dostępne formy i metody działania, przypisane organowi o charakterze policyjnym. Szerokie uprawnienia kontrolne, operacyjno-rozpoznawcze oraz dochodzeniowo-śledcze warunkują skuteczność podejmowanych działań, jak i realizacji nałożonych celów oraz generują określony tryb postępowania, umieszczając go w ramach wskazanych obowiązującym systemem prawnym.

15 Zjawisko to, jak również jego potencjał będzie możliwe do wyświetlenia, głębszego zbadania, po dokładnym zapoznaniu się z tezami zawartymi w niniejszej pracy oraz dokładnym śledzeniu potencjału gier zagranicznych wywiadowni.

16 W pierwszym okresie konwersji (przemiany, zmiany) osoby takie są szczególnie nacechowane żarliwością w wyznawaniu nowej wiary, czym niejednokrotnie zaskakują nawet wyznawców danej religii. W Europie szczególnie niebezpieczni są konwertyci, obywatele RFN oraz UK, odbywający szkolenia w komórkach Al-Kaidy i powracający do kraju pochodzenia lub podejmujący się działań na terenie obszarów objętych konfliktami. Zgodnie z nową koncepcją Al-Kaidy, nie są tam jednak postrzegani jako idealna alokacja środków. Znacznie sprawniejszą rolę przypisuje się im, umieszczając ich w rodzimych krajach, jako rezydentów mających zakładać własne komórki podległe centrali terrorystycznej, z silną bazą agenturalną (wzór działań wywiadowczych służb państwowych, wśród których niestety odnotowywane są w opisywanych obszarach przypadki przechodzenia na tzw. drugą stronę). W samych Niemczech obserwuje się od kilkudziesięciu do kilkuset takich osób.

17 Szczególnie silnie dostrzegane są tego typu przypadki w więzieniach Europy Zachodniej. W Polsce powstały procedury zbierania informacji w tym zakresie, których wykorzystanie nie sygnalizuje znaczącego problemu. Wskazać należy również na zadania Straży Granicznej w tym w obszarze, która to od niedawna administruje i odpowiada za areszty w celu wydalenia z Polski cudzoziemców. 
Od lat dziewięćdziesiątych XX wieku, Straż Graniczna przeobrażała się w wiodącą polską służbę imigracyjną, ochraniającą jednocześnie granicę państwową RP. Realizując proces przeobrażenia, formacja uzyskiwała nowe zadania i nowe uprawnienia umożliwiające zapobieganie i przeciwdziałanie nielegalnej migracji, a także zwalczanie przestępczości transgranicznej, w tym organizacji nielegalnego przekraczania granicy państwowej RP. Znaczenie Straży Granicznej jako służby imigracyjnej wzrosło zarówno po przystapieniu Polski do UE, jak i po przystąpieniu do pełnej realizacji układu z Schengen. Szczególna jej rola wynika z ochrony jednego z najdłuższych odcinków lądowej zewnętrznej granicy zarówno Unii Europejskiej, jak i NATO oraz przyjęcia przez Polskę zobowiązań zawartych w układzie z Schengen. Straż Graniczna prowadzi bieżący monitoring zdarzeń związanych z nielegalną migracją oraz sytuacją na granicy. Monitoring ten wskazuje m.in. na zjawiska, których charakter może być ściśle związany ze zniesieniem kontroli na odcinkach granicy wewnętrznej UE, a wykorzystywany może być przez grupy terrorystyczne. Działania pionu operacyjno-śledczego SG ukierunkowane są na monitorowanie potencjalnych zagrożeń, ze strony zidentyfikowanych oraz nowych grup przestępczych, jak i potencjalnego wzrostu ich aktywności. Zgodnie z zatwierdzonymi przez ministra spraw wewnętrznych i administracji Założeniami wieloletniej koncepcji funkcjonowania Straży Granicznej (2009-2015) strategia rozwoju Straży Granicznej, kompatybilna ze strategicznymi programami rządowymi, zakłada dalsze przeobrażenie formacji w nowoczesną służbę graniczno-imigracyjną o charakterze policyjnym. Profil zadań ulegał będzie konsekwentnym zmianom w celu zwiększenia roli formacji jako służby imigracyjnej, posiadającej możliwość skutecznego rozpoznawania, zapobiegania i zwalczania przestępczości, uwzględniającej udział cudzoziemców lub mającej charakter transgraniczny w zakresie właściwości SG oraz przeciwdziałania zjawisku nielegalnej migracji pobytowej i tranzytowej. Polska, położona na trasie szlaków komunikacyjnych wschód-zachód, pełni rolę kraju tranzytowego dla nielegalnej migracji. Napięcia polityczne i społeczne w innych państwach stymulują zjawisko migracji ludności w kierunku Polski, postrzeganej coraz częściej przez legalnych i nielegalnych migrantów nie tylko jako obszar tranzytowy, lecz jako państwo docelowe. Wzrostowi presji migracyjnej towarzyszy eskalacja zorganizowanego procederu przerzutu i handlu ludźmi, gdyż większość nielegalnych migrantów korzysta z pomocy zorganizowanych grup przestępczych w pokonywaniu granic. Modus operandi sprawców organizowania nielegalnego przekroczenia granicy od wielu lat jest podobny. Zmieniają się jedynie rejony dokonywanych przerzutów, w zależności od stopnia zabezpieczenia odcinka granicy. Struktura narodowościowa nielegalnych migrantów od dłuższego czasu także pozostaje bez większych zmian.

W celu efektywnego zwalczania problemu nielegalnej migracji Straż Graniczna prowadzi w sposób ciąły szkolenia przeznaczone dla funkcjonariuszy SG mające na celu podnoszenie ich kwalifikacji zawodowych. Ponadto, funkcjonariusze SG biora udział w szkoleniach organizowanych we współpracy z innymi państwami członkowskimi UE. Prowadzona jest również współpraca na poziomie krajowym z policją i prokuraturą w ramach kontroli legalności pobytu cudzoziemców oraz z Państwową Inspekcją Pracy i Służbą Celną w ramach kontroli legalności zatrudnienia cudzoziemców oraz na poziomie międzynarodowym, ze służbami państw sąsiednich, z oficerami 
łącznikowymi organów ścigania akredytowanymi w RP, oficerami łącznikowymi akredytowanymi przy przedstawicielstwach RP za granica, jak również za pośrednictwem Biura Międzynarodowej Współpracy Policji, a także współpraca z Europolem i Interpolem. Dodatkowo, w razie potrzeby, tworzone są na podstawie aktów prawnych międzynarodowe, wspólne zespoły i grupy dochodzeniowe.

Straż Graniczna w ramach walki z nielegalną migracją (jednym z elementów działań terrorystycznych), m.in. obserwuje szlaki migracyjne (dotyczy to szczególnie państw o przejrzystej strukturze narodowościowej, jakim po okresie wojen jest Polska). Wśród nich należy wskazać zarówno te, które niosą istotnie duży potencjał zagrożenia, tj. stare szlaki, wiodące z Afganistanu, Pakistanu, republik kaukaskich, jak $\mathrm{i}$ te utworzone stosunkowo niedawno ${ }^{18}$. Przykładem są fale migracyjne $z$ Gruzji ${ }^{19} \mathrm{i}$ Iraku. W Gruzji dominuje prawosławie, lecz drugą religią w tym wielonarodowym społeczeństwie pozostaje islam, kojarzony niezmiennie jako ideologiczny fundament działań terrorystycznych „nadmiernie motywowanych” wspomnianą religią. Irak jest natomiast jednym z najbardziej niebezpiecznych (choć głównie dla własnych obywateli) państw świata, gdzie dochodziło do ok. 150 ataków terrorystycznych tygodniowo, z ogólną liczbą ok. 100 zabitych w każdym. Skłania to ludność do masowego opuszczania miejsc zamieszkania. Obecna liczba uchodźców wewnętrznych przebywających w Iraku to ok. $3 \mathrm{mln}$. Poza granicami tego państwa przebywa ok. 2 mln uchodźców. Głównym kierunkiem nielegalnej migracji jest w tym przypadku RFN, jednakże wraz

18 Znamienne są fakty, iż po wizytach ówczesnego prezydenta RP, Lecha Kaczyńskiego w Gruzji presja migracyjna z tego państwa w kierunku Polski zwiększyła się o ok. sto razy (w 2007 roku ok. 40 uchodźców, w 2009 roku ok. 4 tys. z czego część pozostała w RP). Identyczna sytuacja wystąpiła w związku z działaniami wojennymi w Czeczenii i poparciem rządu polskiego dla tej społeczności - tylko w latach 2007-2009 ok. 25 tys. cudzoziemców złożyło w RP wniosek o nadanie statusu uchodźców, z czego około 1/3-1/4 pozostała w kraju. Oczywiście aspekty humanitarne winny mieć znaczącą rolę $\mathrm{w}$ bieżącej polityce, jednakowoż powinno się to odbywać z przyjęciem pragmatycznych zasad. Przykładem takiego rozwiązania są Niemcy, których system polega na przyjmowaniu precyzyjnie określonych liczebnie grup cudzoziemców, zapewnienia im opieki, pracy oraz zobowiązywania do określonego zachowania, a w ostateczności również wymuszania go.

19 W okresie od 2003 do końca 2008 roku niewiele ponad 200 obywateli Gruzji złożyło wnioski o nadanie statusu uchodźcy. Od stycznia do 31 lipca 2009 roku odnotowano znaczny wzrost liczby wniosków o nadanie statusu uchodźcy składanych przez obywateli Gruzji (2304 co stanowi ponad $43 \%$ ogólnej liczby wniosków składanych w RP). Od kwietnia do 31 lipca 2009 roku był to przyrost gwałtowny (56 - kwiecień, 104 - maj, 883 - czerwiec, 1254 - lipiec) w stosunku do 5 wniosków w marcu 2011 roku. Cudzoziemcy wjeżdżają do RP głównie z terytorium Białorusi, gdzie docierają drogą lotniczą z Tbilisi do Mińska, a stamtąd pociagiem do Brześcia i granicy z Polską. Złożenie wniosku następuje na kolejowym przejściu granicznym (Placówka Straży Granicznej - PSG) w Terespolu. Do połowy kwietnia 2009 roku cudzoziemcy podróżowali indywidualnie, po czym pojawiły się grupy, których liczebność systematycznie wzrastała. Najczęściej są to rodziny. Są to zarówno mężczyźni, jak i kobiety. Wiek wnioskodawców kształtuje się zazwyczaj w przedziale od 21 do 35 lat oraz do 18. roku życia. Osoby nieletnie (32\% ogółu) najczęściej podróżują w towarzystwie rodziców (rzadziej krewnych), przy czym nierzadko tylko z ojcami. Cudzoziemcy deklarują obywatelstwo gruzińskie, natomiast narodowość kurdyjską (ponad 80\%). Zdecydowana większość podaje jako miejsce zamieszkania Tbilisi (ok. 80\%). Wnioskujący jako powód ubiegania się o status uchodźcy w RP podają prześladowania z powodów religijnych narodowościowych i obawy o życie w związku z niestabilną sytuacją panującą w Gruzji. Przyczyną do podjęcia takiej decyzji jest również prowadzony przez rząd w Tbilisi pobór do wojska gruzińskiego. Migracja obywateli Gruzji ma głównie charakter ekonomiczny. 
ze wzrostem dobrobytu w Polsce coraz większa liczba migrantów dociera i pozostaje w RP. Według rządu Iraku ponad 1 mln uchodźców przebywa w Syrii i obecnie liczba ta stale rośnie ${ }^{20}$. Około 700 tys. Irakijczyków mieszka w Jordanii. Z państw tych UE zdecydowała się przyjąć 10 tys. Irakijczyków (jedna czwarta trafi do RFN, gdzie obecnie przebywa prawie 75 tys. osób narodowości irackiej) ${ }^{21}$.

Jak wspomniano, dżihad wspierany może być również przy wykorzystaniu migracji. Wysoce prawdopodobne jest, że będzie ona rosła do państw UE. Z tego względu, oprócz powodów humanitarnych, UE kształtując politykę osiedleniową, nie może pominąc niebezpieczeństw niesionych na fali braku asymilacji ${ }^{22}$ coraz większej liczby obcokrajowców, szczególnie tych o sprecyzowanych, niekorzystnych dla organizacji przekonaniach. Winno to również skłaniać służby do prowadzenia rozpoznania zjawiska włącznie z jego prognozowaniem na poziomie strategicznym oraz operacyjnym i taktycznym Powyższe pozostaje jednym z zadań Straży Granicznejej

\section{TERRORYSTA $^{24}$ - KIM JEST? PRZESTĘPSTWA O CHARAKTERZE TERRORYSTYCZNYM}

Unia Europejska po raz pierwszy przyjęła środki ograniczające i zapobiegawcze wobec osób i podmiotów uczestniczących w aktach terrorystycznych już w grudniu

\footnotetext{
20 The Integrated Regional Information Networks, http://www.irinnews.org/Report.aspx?reportld $=81018(23.01 .2009)$.

${ }_{21}$ Dla porównania w RP najliczniejszą narodowość obcokrajowców (prócz narodowości wymienionych w ustawie o mniejszościach narodowych) stanowią Wietnamczycy, których liczbę szacuje się na 50 tys.

22 Za przykład służyć może sytuacja we Francji i Szwecji, gdzie pomoc udzielana cudzoziemcom, bez tworzenia precyzyjnych i skutecznych programów asymilacyjnych, doprowadziła do problemów społecznych. Problemy te powodowane są nie tylko niewystarczającymi działaniami państw, lecz postawą samych cudzoziemców. W Centralnym Ośrodku Szkolenia Straży Granicznej w Koszalinie przeprowadzono badania socjologiczne na reprezentatywnej grupie cudzoziemców. Z badań tych wynika, iż odsetek osób, dla których praca jest najistotniejszym wyznacznikiem wartościowego życia, oscyluje zaledwie wokół kilku punktów procentowych. Najwięcej wskazań badanych dotyczy honoru i temu podobnych względów.

${ }_{23}$ Zgodnie z art. 1 ust. 2 pkt 4 ustawy z 12 października 1990 roku o Straży Granicznej (tekst jedn. Dz. U. 2011, Nr 116, poz. 675), formacja prowadzi działania m.in. mające na celu rozpoznawanie, zapobieganie i wykrywanie przestępstw i wykroczeń dotyczących zgodności przekraczania granicy państwowej z przepisami, związanych z jej oznakowaniem oraz dotyczących wiarygodności dokumentów uprawniających do przekraczania granicy państwowej. Podstawę prawną stanowią również: Koncepcja funkcjonowania Straży Granicznej w latach 2009-2015, zatwierdzona przez Komendanta Głównego Straży Granicznej 24 września 2009 roku (do użytku służbowego); Program zintegrowanego zarzqdzania granicq na lata 2007-2013, przyjęty przez Radę Ministrów 20 września 2007 roku (do użytku służbowego); Strategia bezpieczeństwa narodowego Rzeczypospolitej Polskiej, przyjęta przez Radę Ministrów 5 listopada 2007 roku, http://www.mon.gov.pl/pliki/File/zalaczniki_do_stron/SBN_RP.pdf(10.11.2011); Rozporzqdzenie (WE) nr 562/2006 Parlamentu Europejskiego i Rady z 15 marca 2006 roku ustanawiajace wspólnotowy kodeks zasad regulujacych przeplyw osób przez granice, Kodeks graniczny Schengen, Dz. U. UE L 2006, nr 105, poz. 1.

${ }^{24}$ Oznacza osoby, grupy lub podmioty wymienione w załączniku do wspólnego stanowiska Rady 2001/931/WPZiB z 27 grudnia 2001 r. w sprawie zastosowania szczególnych środków w celu zwalczania terroryzmu. Patrz: Dz. Urz. UE L 2001, nr 344, poz. 93.
} 
2001 roku, w następstwie ataków terrorystycznych na WTC w Nowym Jorku z 11 września tego roku. Wykaz UE został ustanowiony w celu wdrożenia rezolucji Rady Bezpieczeństwa Organizacji Narodów Zjednoczonych nr 1373 (2001), co przyjęto na podstawie rozdziału VII Karty Narodów Zjednoczonych.

Opierając się na aktach prawnych o charakterze międzynarodowym Rada UE przyjęła Wspólne stanowisko nr 2001/931/WPZiB z 27 grudnia 2001 roku w sprawie stosowania szczególnych środków do zwalczania terroryzmu oraz rozporządzenie nr 2580/2001 w sprawie zastosowania szczególnych środków ograniczających skierowanych przeciwko niektórym osobom i podmiotom mających na celu zwalczanie terroryzmu. Wspólne stanowisko ustanawia kryteria dla osób, grup lub podmiotów uczestniczących w aktach terrorystycznych i określa definicje czynności, które stanowią akty terrorystyczne. Rozporządzenie przewiduje natomiast zamrożenie wszystkich funduszy oraz innych aktywów finansowych i zasobów gospodarczych należących do osób, grup i podmiotów. Ponadto stwierdza, że fundusze i inne aktywa finansowe i zasoby gospodarcze mogą być udostępnione dla nich bezpośrednio lub pośrednio (głównie w celu zapewnienia możliwości samodzielnej egzystencji na podstawowym poziomie ze względów humanitarnych).

Wszystkie osoby, grupy i jednostki umieszczone w wykazie załączonym do Wspólnego stanowiska podlegają zaostrzonym środkom dotyczącym współpracy policyjnej i sądowej i współpracy w sprawach karnych ujętych w Traktacie o Unii Europejskiej. Ponadto aktywa i fundusze osób, grup i podmiotów, które są ujęte na liście w cytowanym rozporządzeniu podlegają zamrożeniu przez wszystkie państwa członkowskie UE. Lista UE jest niezależna od unijnego systemu wykonania rezolucji RB ONZ nr 1390 (2002) w sprawie zamrożenia funduszy osób i podmiotów związanych z Osamą bin Ladenem, siecią Al-Kaida i Talibami. Tę kwestię reguluje rozporządzenie Rady (WE) nr 881/2002.

Wspólne stanowisko Rady nr 2001/931/WPZiB ma zastosowanie do osób, grup i podmiotów uczestniczących w aktach terrorystycznych, gdy decyzja taka została podjęta przez właściwy, uprawniony organ. Przedmiotowa decyzja może dotyczyć wszczęcia dochodzenia lub postępowania w sprawie o akt terrorystyczny, próby przeprowadzenia lub ułatwienia dokonania takiego aktu, opartego na poważnych i wiarygodnych dowodach lub poszlakach, lub skazania prawomocnym wyrokiem sądowym za takie czyny. Decyzja taka może zostać wydana również przez właściwą władzę, gdy władze sądownicze nie mają właściwości miejscowej i rzeczowej na danym obszarze.

Artykuł 1(3) omawianego wspólnego stanowiska określa znaczenie pojęcia akt terrorystyczny. Termin ten oznacza zamierzony czyn, który ze względu na swój charakter i kontekst może wyrządzić poważne szkody dla państwa lub organizacji międzynarodowej, a które są określone jako przestępstwo w rozumieniu prawa krajowego. Przestępstwa te obejmują: ataki na życie ludzkie, które mogą spowodować śmierć; ataki na integralność cielesną osoby; porwania lub branie zakładników; spowodowanie rozległych zniszczeń obiektów rządowych lub obiektów użyteczności publicznej, systemu transportowego, infrastruktury; zajęcie statku powietrznego, statków morskich lub innych środków transportu publicznego lub towarowego; wytwarzanie, posiadanie, nabywanie, przewożenie, dostarczanie lub używanie broni, materiałów wybuchowych lub broni jądrowej, biologicznej lub chemicznej; uczestniczenie w działalności grupy terrorystycznej, w tym poprzez dostarczanie informacji lub zasobów materialnych lub 
finansowanie jej działalności w jakikolwiek sposób, ze świadomością faktu, że udział ten przyczyni się do przestępczej działalności tej grupy.

Aby akty te stanowiły przestępstwo o charakterze terrorystycznym, muszą zostać przeprowadzone w celu poważnego zastraszenia ludności, lub bezprawnego zmuszenia rządu lub organizacji międzynarodowej do wykonania lub powstrzymania się od wykonania jakiegokolwiek działania, lub poważnej destabilizacji lub zniszczenia podstawowych politycznych, konstytucyjnych, gospodarczych lub społecznych struktur państwa lub organizacji międzynarodowej. W pierwszej połowie 2007 roku, Rada dokonała szczegółowego przeglądu i konsolidacji swoich procedur dotyczących sporządzania wykazu osób, grup i podmiotów, zgodnie z analizowanym wspólnym stanowiskiem oraz rozporządzeniem $\mathrm{nr}$ 2580/2001. W efekcie zostały uzgodnione konkretne zmiany w celu ustalenia, jednolitej i bardziej przejrzystej procedury.

Na tej podstawie ukonstytuowała się Grupa robocza ds. Realizacji Wspólnego Stanowiska Rady nr 2001/931/WPZiB w sprawie zastosowania szczególnych środków w celu zwalczania terroryzmu (dalej: Robocza 931). Robocza 931 zajmuje się rozpatrywaniem wniosków o umieszczenie osób i podmiotów na liście oraz przygotowaniem regularnego przeglądu stworzonego wykazu przez Radę. Jak przewidziano w artykule 1 wspólnego stanowiska nr 2001/931/WPZiB Robocza 931 zastępuje mechanizm konsultacji między państwami członkowskimi, które obowiązywały od 2001 roku. Osoby, grupy i podmioty mogą zostać umieszczone na liście na podstawie wniosków składanych przez państwa członkowskie lub państwa trzecie. W tym przypadku wniosek powinien zawierać wszystkie istotne informacje w przedmiocie umieszczenia osoby, grupy lub podmiotu na liście. Informacje te są przekazywane delegacjom państw członkowskich do dyskusji w ramach Grupy Roboczej 931. Grupa analizuje i ocenia otrzymane we wniosku informacje w celu umieszczenia lub usunięcia osób, grup i podmiotów z listy. Grupa zajmuje się również zaleceniami dotyczącymi modelu przekazywania i umieszczania danych w wykazie. W następstwie tworzone w ten sposób instrumenty prawne zostaną przyjęte przez Radę i są publikowane w Dzienniku Urzędowym UE. W uzasadnionych przypadkach obrady i działania Grupy Roboczej 931 chronione są klauzulą poufności w celu zagwarantowania przewidzianych prawem wymogów ochrony informacji niejawnych.

Dla każdej osoby, grupy i podmiotu podlegającego ograniczeniom na mocy rozporządzenia $\mathrm{nr}$ 2580/2001, Rada sporządza uzasadnienie, które jest na tyle szczegółowe, aby umożliwić osobom i podmiotom zainteresowanym zrozumieć przyczyny umieszczenia ich na wykazie, jak również aby umożliwić wspólnotowym organom sądowym wykonywanie ich uprawnień kontrolnych, w przypadku złożenia przez zainteresowany podmiot formalnego zażalenia na fakt umieszczenia na przedmiotowej liście. Uzasadnienie wyjaśnia, jak kryteria określone we wspólnym stanowisku zostały spełnione i wzięte pod uwagę w momencie umieszczenia na liście. Sentencja decyzji określa, że osoba, grupa lub podmiot został uznany za uczestnika zdarzenia o charakterze terrorystycznym. Decyzja obejmuje następujące szczegółowe dane na temat:

- aktów terrorystycznych popełnionych w odniesieniu do odpowiednich przepisów Wspólnego Stanowiska Rady nr 2001/931/WPZiB;

- charakteru i identyfikacji właściwego organu, który podjął decyzję w sprawie umieszczenia osoby, grupy lub podmiotu na liście; 
- rodzaju podjętej decyzji, z uwzględnieniem właściwych przepisów Wspólnego Stanowiska Rady nr 2001/931/WPZiB.

O decyzji Rady i o umieszeniu na liście Sekretariat Generalny Rady informuje pisemnie każdą osobę, grupę i podmiot podlegający ograniczeniom na mocy analizowanego rozporządzenia w przypadku, gdy jest to możliwe ${ }^{25}$. Zawiadomienie zostaje opublikowane w Dzienniku Urzędowym UE w celu informowania osób, grup i podmiotów, podlegających ograniczeniom. Zawiadomienie służy również informowaniu osób, grup i podmiotów, których adres nie jest znany o możliwości skorzystania z uprawnień przysługujących tym podmiotom związku z umieszczeniem ich przez Radę na liście. Ponadto, w momencie wpisania organizacji terrorystycznej lub osoby powiązanej z terroryzmem na listę, informacja taka trafia (powinna trafić) do systemu baz danych organów Unii Europejskiej odpowiedzialnych za ochronę ładu, bezpieczeństwa i porządku publicznego państw członkowskich, oraz stron układu z Schengen. Chodzi o System Informacyjny Schengen i Systemu Informacji Wizowej. Każde z państw członkowskich utrzymuje również narodowe systemy informacyjne, w których umieszczane są takie informacje. W przypadku Polski, wykaz osób niepożądanych prowadzony przez Szefa Urzędu do spraw Cudzoziemców. Zgodnie z art. 124 ust. 1 pkt 4 ustawy z 13 czerwca 2003 r. o cudzoziemcach ${ }^{26}$ w sprawach z zakresu wjazdu, pobytu i wyjazdu cudzoziemców z terytorium Rzeczypospolitej Polskiej prowadzi się w systemie informatycznym, wykaz cudzoziemców, których pobyt na terytorium Rzeczypospolitej Polskiej jest niepożądany.

Rada dokonuje przeglądu wykazu w regularnych odstępach czasu, co najmniej raz na sześć miesięcy. Państwa członkowskie informują się wzajemnie o wszelkich nowych faktach i zdarzeniach dotyczących aktualizacji listy. W pismach kierowanych do zainteresowanych osób, grup i podmiotów zawiera się sugestie dotyczące przedstawienia swoich poglądów dotyczących przyczyn umieszczenia na liście. Dla celów kontroli, Grupa Robocza 931 przeprowadza ocenę zasadności umieszczenia na liście poszczególnych podmiotów. W tym przypadku Grupa bierze pod uwagę wszystkie istotne okoliczności, w tym osoby, grupy lub podmioty, ich poprzednie udziały w incydentach o charakterze terrorystycznym, obecny status grupy lub podmiotu, jak również rokowania co do przyszłych zamiarów osoby, grupy lub podmiotu. Po przeprowadzeniu takiej oceny, Robocza 931 wydaje zalecenia, co do kolejnego uaktualnienia przez Radę listy, jak również dotyczące uwzględnienia nowych niezbędnych instrumentów prawnych, które winny być przyjęte przez Radę. Niezależnie od regularnego przeglądu Rada może w każdej chwili przyjąć decyzję o umieszczeniu w wykazie lub usunięciu z niego nowych osób, grup i podmiotów. Ponadto, skreślenie z listy wymienionych osób, grup i podmiotów może nastąić na wniosek wystosowany do Rady przez państwo członkowskie lub państwo trzecie, które wcześniej zaproponowało umieszczenie

${ }^{25} \mathrm{~W}$ piśmie wskazane są m.in. środki ograniczające, przywołane są ewentualne odstępstwa wynikające ze względów humanitarnych (np. jeśli część zamrożonych środków ma być wykorzystana na podstawowe potrzeby), podane jest uzasadnienie decyzji, a także pouczenie o przysługujących środkach odwoławczych (np. możliwość wniesienia skargi do Sądu I Instancji). W piśmie ujęty jest też wniosek o wyrażenie zgody przez wymienione w decyzji osoby na upublicznienie uzasadnienia.

26 Dz. U. 2006, Nr 234, poz. 1694 z późn. zm. 
podmiotu w wykazie. Obligatoryjnie z wykazu usuwa się podmiot, gdy wygasną kryteria umieszczenia go na liście określone we Wspólnym stanowisku Rady nr 2001/931/WPZiB. Fakultatywne usunięcie następuje w następstwie śmierci osoby lub w przypadku likwidacji wymienionych na liście podmiotów.

Wprowadzając rozwiązania prawne mające umożliwić zwalczanie przestępstw terrorystycznych, Rada przyjęła rozporządzenie nr 2580/2001 w sprawie szczególnych środków restrykcyjnych skierowanych przeciwko niektórym osobom i podmiotom mających na celu zwalczanie terroryzmu ${ }^{27}$. Rozporządzenie to odnosi się do rezolucji Rady Bezpieczeństwa ONZ nr 1373 (2001) i wprowadza w życie jej postanowienia. Rozporządzenie przewiduje zamrożenie wszystkich funduszy, innych aktywów finansowych i zasobów gospodarczych należących do określonych osób, grup lub podmiotów. Stwierdza się w nim ponadto, że tym osobom, grupom i podmiotom nie wolno udostępniać, bezpośrednio ani pośrednio, żadnych funduszy, aktywów finansowych ani zasobów gospodarczych. Rozporządzenie przewiduje również wyłączenia ze względów humanitarnych umożliwiające korzystanie z funduszy w określonych przypadkach, np. w celu płatności za środki spożywcze czy lekarstwa lub pokrycia opłat sądowych. Załącznik do tego dokumentu stanowi lista osób, organizacji i instytucji zaangażowanych w działalność terrorystyczną, wobec których stosuje się przepisy ww. rozporządzenia.

\section{TERRORYZM I PRZESTĘPCZOŚĆ ZORGANIZOWANA ${ }^{28}$ A POLSKIE PRAWO KARNE}

Terroryzm to zaplanowana, motywowana politycznie lub religijnie przemoc, również wobec celów nieuczestniczących w walce, organów władzy i administracji państwowej oraz innych instytucji, społeczeństwa lub osoby, stosowana przez państwa, subnarodowe grupy czy tajnych agentów, zwykle mająca na celu oddziaływanie na audytorium w celu wymuszenia określonego zachowania bądź zastraszenia. Według innej definicji, to świadome użycie siły lub przemocy wobec osób lub mienia naruszające porządek prawny w celu zastraszenia wielu osób oraz zmuszenia organu władzy publicznej do podjęcia lub zaniechania czynności istotnych dla osiagnięcia celów politycznych, religijnych, społecznych lub ekonomicznych.

Przy badaniu zjawisk związanych z terroryzmem, należy wyszczególnić różne podłoża działania sprawców, tj.: ideologiczne, religijne, separatystyczne i nacjonalistyczne. Odrębne podłoża działania charakteryzują przestępczość zorganizowana, gdzie mamy do czynienia głównie z motywacją kryminalną, dążącą do zysków ekonomicznych. Kolejnym podziałem, jakiego należy dokonać, aby rozgraniczyć terroryzm i przestępczość zorganizowana, jest cel działania sprawców. Działania terrorystyczne zmierzają do osiagnięcia celów natury politycznej. Biorąc powyższe pod uwagę, w celu

27 Dz. Urz. UE. L 2009, nr 151.

28 Wskazać można, że terroryzm to zawsze przestępczość zorganizowana (swoisty typ tej zbrodni to przypadki w ramach tzw. działań samotnych wilków, jako narzędzia terrorystycznego przestępczości zorganizowanej), ale przestępczość zorganizowana to nie zawsze terroryzm. 
rozróżnienia zjawiska i dokonania jego właściwej penalizacji, od 1 maja 2004 roku do Kodeksu karnego, Kodeksu postępowania karnego i innych ustaw wprowadzono przestępstwo o charakterze terrorystycznym. Uzupełnienia ustaw spowodowane były postanowieniami decyzji ramowej Rady UE z 13 kwietnia 2002 roku o zwalczaniu terroryzmu, nakazującej m.in. wprowadzenie przestępstwa terrorystycznego do przepisów karnych państw członkowskich, a także przyjęcie wyższych ustawowo kar za jego dokonanie. Do art. $115 \S 20$ k.k. wprowadzono definicję przestępstwa o charakterze terrorystycznym ${ }^{29}$, obejmująca jedynie element celu działania sprawcy. Katalog czynów o charakterze terrorystycznym ograniczono do czynów najpoważniejszych, zagrożonych karą roku pozbawienia wolności, popełnionych z użyciem przemocy lub groźby zamachu na życie lub zdrowie albo gwałtownego zamachu na mienie ${ }^{30}$. Polskie prawo karne materialne penalizuje następujące stany faktyczne związane z przestępstwami mogącymi wypełniać znamiona terroryzmu oraz z użyciem urządzeń i materiałów wybuchowych:

1) zamach lub czynna napaść na prezydenta RP (art. 134 i 135 k.k.);

2) czynna napaść na głowę obcego państwa lub dyplomatę (art. 136 k.k.);

3) zamach terrorystyczny na jednostkę sił zbrojnych RP (art. 140 k.k.);

4) dokonanie zabójstwa przy użyciu materiałów wybuchowych (art. $148 \S 1$ pkt 4);

5) udział w zorganizowanej grupie przestępczej, w tym terrorystycznej (art. 258 k.k.);

6) przestępstwo o charakterze terrorystycznym (art. 115 § 20 k.k.);

7) spowodowanie niebezpiecznych zdarzeń (art. 163 k.k.), w tym eksplozji materiałów wybuchowych (art. $163 \S 1$ pkt 3) - w sprawach kwalifikowanych z tego artykułu nie jest istotny rozmiar wyrządzonej szkody, a jedynie wywołanie eksplozji zagrażającej mieniu $\mathrm{w}$ znacznych rozmiarach. Znamiona tego przestępstwa wypełnia więc samo wywołanie eksplozji, choćby szczęśliwy zbieg okoliczności sprawił, że nie wyrządziła ona znacznej szkody. Zakres szkody jest istotny dla oznaczenia szkodliwości przestępstwa, zatem dla wymiaru kary;

8) sprowadzenie niebezpieczeństwa powszechnego dla życia lub zdrowia (art. 165 k.k.);

9) piractwo powietrzne i wodne (art. 166 i 167 k.k.);

10) przygotowanie przestępstwa $z$ użyciem materiałów i urządzeń wybuchowych (art. 168 k.k.);

11) wyrabianie, przetwarzanie, gromadzenie, posiadanie, posługiwanie się lub handlowanie substancjami lub przyrządami wybuchowymi bez wymaganego zezwolenia,

29 Przestępstwa terrorystyczne, w świetle prawa europejskiego, oznaczają przestępstwa określone w art. 1-3 decyzji ramowej Rady 2002/475/WSiSW z 13 czerwca 2002 roku w sprawie zwalczania terroryzmu. Patrz: Dz. Urz. UE L 2002, nr 164, poz. 3. W rozumieniu prawa polskiego ,przestępstwem o charakterze terrorystycznym" jest czyn zabroniony zagrożony karą pozbawienia wolności, której górna granica wynosi, co najmniej 5 lat, popełniony w celu: 1) poważnego zastraszenia wielu osób, 2) zmuszenia organu władzy publicznej Rzeczypospolitej Polskiej lub innego państwa albo organu organizacji międzynarodowej do podjęcia lub zaniechania określonych czynności, 3) wywołania poważnych zakłóceń w ustroju lub gospodarce Rzeczypospolitej Polskiej, innego państwa lub organizacji międzynarodowej, a także groźba popełnienia takiego czynu.

${ }_{30}$ Nie jest to doskonała definicja. Dla przykładu można przyjąć, że protest górników prowadzony pod kancelarią prezesa Rady Ministrów wypełnić może znamiona czynu terrorystycznego, tj. mającego na celu wypełnienie dyspozycji ust. 2 tegoż artykułu. Należy jednak, z przyczyn oczywistych, przyjąć tę definicję jako wiążącą. 
wbrew jego warunkom (art. 171 k.k.). Opisany czyn jest przestępstwem formalnym, o zaistnieniu którego nie decyduje konkretne i realne niebezpieczeństwo powszechne grożące życiu lub zdrowiu ludzkiemu albo mieniu w znacznych rozmiarach na skutek przechowywania odpowiednich materiałów lub przyrządów, ale sam fakt przechowywania materiałów, które ze swojej istoty są materiałami niebezpiecznymi dla życia ludzkiego lub mienia znacznych rozmiarów. W ocenie tego przestępstwa ważną rolę spełniają dwie ustawy: z 21 czerwca 2002 roku o materiałach wybuchowych przeznaczonych do użytku cywilnego ${ }^{31}$ oraz z 22 czerwca 2001 roku o wykonywaniu działalności gospodarczej w zakresie wytwarzania i obrotu materiałami wybuchowymi, bronią, amunicją oraz wyrobami i technologią o przeznaczeniu wojskowym lub policyjnym ${ }^{32}$. Ustawy te wprowadzaja jednolite definicje materiałów wybuchowych, materiałów pirotechnicznych jako jednej z odmian materiałów wybuchowych oraz materiałów niebezpiecznych;

12) sprowadzenie katastrofy w ruchu lądowym, wodnym lub powietrznym (art. 173 k.k.);

13) groźba karalna (art. $190 \S 1$ k.k.);

14) nieuprawniony przewóz materiałów wybuchowych (art. 63 i 64 ustawy o materiałach wybuchowych przeznaczonych do użytku cywilnego);

15) wykonywanie działalności gospodarczej w zakresie materiałów wybuchowych wbrew koncesji (art. 36 ustawy o wykonywaniu działalności gospodarczej w zakresie wytwarzania i obrotu materiałami wybuchowymi, bronia, amunicją oraz wyrobami i technologią o przeznaczeniu wojskowym lub policyjnym);

16) nielegalna sprzedaż wyrobów pirotechnicznych nieletnim (art. 37 ustawy o materiałach wybuchowych przeznaczonych do użytku cywilnego).

Reasumując, należy stwierdzić, iż polskie prawo reguluje następujące stany faktyczne związane z przestępstwami terrorystycznymi oraz z użyciem urządzeń i materiałów wybuchowych: przestepstwo o charakterze terrorystycznym oraz udział w grupie terrorystycznej; dokonanie zabójstwa przy użyciu materiałów i urządzeń wybuchowych; przygotowanie przestępstwa z użyciem materiałów i urządzeń wybuchowych; wyrabianie, przetwarzanie, gromadzenie, posiadanie, posługiwanie się lub handlowanie substancjami lub przyrządami wybuchowymi bez wymaganego zezwolenia lub wbrew jego warunkom. W niedalekiej przyszłości rozszerzy się o ściganie przestępstwa rozpowszechniania za pośrednictwem Internetu materiałów propagandowych dotyczących terroryzmu oraz nakłaniania do działań terrorystycznych. Jednym z najważniejszych postulatów w zakresie walki z terroryzmem, które zostały zrealizowane dzięki zmianom w polskim prawie, było stworzenie prawnych mechanizmów zapobiegania finansowania terroryzmu ${ }^{33}$.

Porównując polski system karny z systemami państw o większym, praktycznym doświadczeniu w ściganiu tego typu czynów, należy stwierdzić, iż jest on zbliżony co do zakresu i mocy obowiązywania ${ }^{34}$ (choć oczywiście nie dotyczy to specjalnych

31 Dz. U. 25 lipca 2002, Nr 117, poz. 1007.

32 Dz. U. 29 czerwca 2001, Nr 67, poz. 679

33 Ustawa z 16 listopada 2000 roku o przeciwdziałaniu praniu pieniędzy oraz finansowaniu terroryzmu, tekst jedn. Dz. U. 2010, Nr 46, poz. 276.

34 Fundamentalną sprawą jest brak w Polsce narodowej strategii zwalczania terroryzmu (nazwanej obecnie z przyczyn formalno-organizacyjnych Narodowym Programem Antyterrorystycznym). Pomimo precyzyjnych dokumentów w tej sprawie, przygotowanych przez różne gremia (m.in. Biuro 
ustaw antyterrorystycznych). Najbardziej rygorystyczne przepisy w tych sprawach obowiązują w Wielkiej Brytanii, USA, Niemczech i Francji. Dla przykładu, ustawodawstwo brytyjskie przewiduje karę dożywotniego pozbawienia wolności za spowodowanie wybuchu niezależnie od tego, czy spowodowało to zagrożenie dla życia lub poważne zniszczenia. Niemieckie ustawodawstwo przewiduje karę dożywotniego pozbawienia wolności lub karę na czas nie krótszy niż 10 lat dla sprawcy, który umyślnie spowodował wybuch albo eksplozję, powodując śmierć drugiego człowieka. W polskim prawie za taki czyn grozi kara od 2 do 12 lat pozbawienia wolności ${ }^{35}$. Prawo amerykańskie stanowi, że sąd nie może orzec kary w zawieszeniu wobec osób, które dopuściły się przestępstw z użyciem materiałów wybuchowych. W unormowaniach karnych USA i Francji zaostrzonej karze podlegają sprawcy, którzy dokonują zamachów terrorystycznych przy użyciu materiałów wybuchowych na obiekty państwowe. Równie istotny, z punktu widzenia sprawności systemu ścigania sprawców tego typu przestępstw, jest system zachodni (np. zastosowany w RFN), gdzie postępowania przygotowawcze prowadzone w wyżej wymienionym zakresie w całości powierzane są organom Policji Federalnej, instytucjonalnie porównywalnej do polskiego Centralnego Biura Śledczego Komendy Głównej Policji.

\section{ROLA STRAŻY GRANICZNEJ W ROZPOZNANIU I PRZECIWDZIALANIU ZAGROŻENIOM TERRORYZMEM}

Straż Graniczna, jako jedyna formacja o charakterze policyjnym, (podobne rozwiązania posiadaja jedynie służby specjalne ${ }^{36}$, głównie ABW) posiada w ustawie kompetencyjnej zapis, świadczący o jej roli w zakresie walki z terroryzmem. W art. 1 ust. 2 pkt 5d ustawy z 12 października 1990 roku o Straży Granicznej ${ }^{37}$ wprowadzono formułę nakładającą na formację obowiązek, ,prowadzenia czynności w celu rozpoznawania

Bezpieczeństwa Wewnętrznego oraz Zespół do spraw przeglądu polskich przepisów prawnych w zakresie terroryzmu), zastępuje się ją nieadekwatną w tym zakresie koncepcją zwalczania przestępczości zorganizowanej w wymiarze praktycznym. W wymiarze ogólnym odniesieniem jest Strategia bezpieczeństwa narodowego Rzeczypospolitej Polskiej podpisana przez Prezydenta RP 13 listopada 2007 roku. Brakuje również tzw. ustawy antyterrorystycznej (lub innego dokumentu o stosownym umocowaniu prawnym - strategii), która miałaby precyzować nie tylko służbę odpowiedzialną za nadzór nad poszczególnymi przedsięwzięciami, ale tworzyć ponadresortowy system obejmujący kompleksową wizję kontrterrorystyczną z elementami rozpoznawania, przeciwdziałania i zwalczania.

35 Jednocześnie można powątpiewać, czy wysokość kar dla sprawców przestępstw o charakterze terroryzmu politycznego nadmiernie motywowanego religią islamu (główne zagrożenie terrorystyczne w RP) ma jakiekolwiek znaczenie.

36 Ustawa z 24 maja 2002 roku o Agencji Bezpieczeństwa Wewnętrznego oraz Agencji Wywiadu, tekst jedn. Dz. U. 2010, Nr 29, poz. 154. W art. 5 ust. 1 pkt 2 wśród zadań ABW wymienia „rozpoznawanie, zapobieganie i wykrywanie przestępstw terroryzmu". Ustawa z 9 czerwca 2006 roku o Stużbie Kontrwywiadu Wojskowego oraz Stużbie Wywiadu Wojskowego, Dz. U. 2006, Nr 104, poz. 709. $\mathrm{W}$ art. 5 ust. 1 pkt $1 \mathrm{~g}$ wśród zadań SKW wymienia „rozpoznawanie, zapobieganie oraz wykrywanie popełnianych przez żołnierzy pełniących czynną służbę wojskową, funkcjonariuszy SKW i SWW oraz pracowników SZ RP i innych jednostek organizacyjnych MON, przestępstw związanych z działalnością terrorystyczną [...]".

37 Dz. U. 2011, Nr 116, poz. 675. 
i przeciwdziałania zagrożeniom terroryzmem". Artykuł ten, niestety, nie został doprecyzowany. Ustawodawca nie wskazał takiego obowiązku, nie zobowiązał do tego również np. ministra spraw wewnętrznych i administracji. To rozwiązanie kłopotliwe dla formacji, która musiała, odnosząc się do własnych ogólnych ustawowych kompetencji, ujętych w art. 1 wymienionej wyżej ustawy, doregulować tę kwestię we własnym zakresie. W takiej sytuacji pomocna mogłaby być, nieistniejąca jeszcze, narodowa strategia antyterrorystyczna. Strategia taka powinna być filarem dla działań instytucji, służb i innych elementów, wedle którego budowano by w nich mechanizmy korelujące na podstawie strategii w jeden sprawnie funkcjonujący system zwalczania zagrożeń terrorystycznych ${ }^{38}$.

Mając na względzie wyżej wymienione zapisy ustawowe, po stworzeniu podstaw do właściwego funkcjonowania utworzono w pionie operacyjno-śledczym SG specjalną podstrukturę, która skupia oraz merytorycznie koordynuje łącznie kilkuset funkcjonariuszy (etatowych i nieetatowych). Ogólnie, przedsięwzięcia formacji koncentrują się m.in. na:

- rozpoznawaniu, zapobieganiu i wykrywaniu przestępstw i wykroczeń oraz ściganiu ich sprawców, a w szczególności przestępstw pozostających w związku z przekraczaniem granicy państwowej lub przemieszczaniem przez tę granicę towarów oraz przedmiotów określonych w przepisach o broni, amunicji i materiałach wybuchowych;

- zapewnieniu bezpieczeństwa w międzynarodowej komunikacji lotniczej, przez prowadzenie kontroli bezpieczeństwa pasażerów, bagaży, ładunków i statków powietrznych realizujących loty wysokiego ryzyka oraz prowadzeniu działań minersko-pirotechnicznych;

- utrzymaniu ładu i porządku publicznego w zasięgu terytorialnym przejść granicznych, w tym ochronę obiektów należących lub użytkowanych przez Straż Graniczną przed aktami terrorystycznymi;

- zapobieganiu przekroczeniu granicy RP przez osoby niepożądane oraz zatrzymywaniu osób poszukiwanych przez organa ścigania;

- zapewnieniu bezpieczeństwa w portach lotniczych i morskich, ze względu na ich znaczenie strategiczne;

- gromadzeniu i analizowaniu informacji dotyczących obywateli państw tzw. podwyższonego ryzyka, przekraczających granicę państwową na przejściach granicznych lub usiłujących przekroczyć ją nielegalnie poza przejściami. W stosunku do obywateli m.in. wskazanych wyżej państw SG wydaje opinie w sprawie udzielania wiz przez urzędy konsularne RP;

- monitorowaniu środowisk i skupisk osób pochodzących z państw tzw. podwyższonego ryzyka, powiązanych z przestępczością graniczną;

- kontrolowaniu skali przewozów dużych sum pieniędzy przez granicę państwową;

38 Należy podkreślić, iż pojawiły się symptomy zmian w tym zakresie. Powyższe rozważania płyną z przekonania autora niniejszej pracy, który tworzył tego typu wewnętrzne uregulowania Straży Granicznej, był uczestnikiem zespołu ds. utworzenia zapisów tzw. ustawy antyterrorystycznej oraz jest uczestnikiem zespołu redagującego Narodowy Program Antyterrorystyczny. 
- współdziałaniu i prowadzeniu wymiany oraz weryfikacji informacji w zakresie przeciwdziałania zagrożeniom terrorystycznym z Agencją Bezpieczeństwa Wewnętrznego, Agencją Wywiadu, Służbą Kontrwywiadu Wojskowego, Służbą Wywiadu Wojskowego, Policją, Biurem Ochrony Rządu, Ministerstwem Finansów, Ministerstwem Spraw Zagranicznych, Żandarmerią Wojskową oraz z organami ochrony granicy państw sąsiednich, jak również innymi służbami i instytucjami krajowymi i międzynarodowymi;

- przeciwdziałaniu przemytowi przez granicę państwową materiałów wybuchowych, broni, amunicji, materiałów promieniotwórczych (przejścia graniczne są wyposażone w stacjonarne i przenośne urządzenia dozymetryczne, służące do wykrywania, pomiaru i identyfikowania izotopów promieniotwórczych), niebezpiecznych środków chemicznych i materiałów podwójnego zastosowania. W tym celu do kontroli wykorzystywane są m.in. specjalne psy służbowe oraz urządzenia wykrywające śladowe ilości i pary materiałów wybuchowych;

- przeciwdziałaniu i wykrywaniu wykorzystywania wiz do przyjazdu do RP pod pozorem podjęcia nauki, kontaktów gospodarczych czy też kulturalnych;

- przeciwdziałaniu i wykrywaniu pozornych małżeństw zawieranych z obywatelem RP w celu otrzymania, po 3 latach takiego małżeństwa, obywatelstwa polskiego;

- inne, niejawne działania.

Intensywność i zakres działań, dostosowywane są do aktualizowanej oceny zagrożenia, którą formacja wypracowuje w ramach jednolitych projektów ze służbami specjalnymi. Funkcjonariusze SG, wykonując ustawowe zadania, mają ponadto prawo dokonywania kontroli osobistej, a także przeglądania zawartości bagaży, sprawdzania ładunków w portach i na dworcach oraz w środkach komunikacji lotniczej, drogowej, kolejowej i wodnej, w celu wykluczenia możliwości popełnienia przestępstw lub wykroczeń. Kontroli osobistej dokonuje się w szczególności w przypadku ujawnienia przy osobie przedmiotów, które mogą stanowić zagrożenie dla bezpieczeństwa w komunikacji międzynarodowej. Kontrolę dokumentów podróży ułatwia opracowany przez SG Album wzorów dokumentów uprawniajacych do przekraczania granicy państwowej Rzeczypospolitej Polskiej oraz sposobu jego prowadzenia, a w niedalekiej przyszłości projekt SG E-paszport. Od 2003 roku uruchomiona została elektroniczna wersja tej bazy danych. Jest ona dostępna we wszystkich granicznych jednostkach organizacyjnych SG. Zadania z zakresu kontroli radiometrycznej wykonują funkcjonariusze - radiometryści, przeszkoleni na podstawie programu szkolenia zatwierdzonego przez komendanta głównego Straży Granicznej i zaakceptowanego przez prezesa Państwowej Agencji Atomistyki. O skuteczności ich działań decyduje, oprócz przygotowania fachowego, jakość urządzeń dozymetrycznych. Do kontroli materiałów promieniotwórczych SG wykorzystuje stacjonarne monitory promieniowania gamma i gamma-neutronowego oraz urządzenia przenośne. Kontroli poddawane są środki transportu, osoby oraz przewożone i przenoszone przedmioty. W ramach radiologicznej ochrony państwa funkcjonariusze Straży Granicznej mają prawo zawrócić do nadawcy transporty lub przesyłki z materiałami promieniotwórczymi, zarówno z uwagi na brak zezwoleń na ich przemieszczanie, jak i przekroczenie dopuszczalnych norm promieniowania.

Zadania w zakresie przeciwdziałania zagrożeniom terrorystycznym realizowane są również przez służbę operacyjno-śledczą SG. Od 2001 roku do zwalczania określo- 
nych, najgroźniejszych rodzajów przestępstw wykorzystuje ona znacznie rozszerzone uprawnienia, obejmujące m.in. zakup kontrolowany, przesyłkę niejawnie nadzorowaną, środki kontroli technicznej, obserwację i kontrolę operacyjną, operacje specjalne.

Straż Graniczna ma w swojej strukturze wyspecjalizowane i szczególnie starannie dobierane zespoły minersko-pirotechniczne, powołane na lotniczych przejściach granicznych. Zespoły te zajmują się rozpoznawaniem i neutralizacją zagrożeń bombowych na lotniskach. Sa one wyposażone w wysokiej klasy sprzęt specjalistyczny wykorzystywany do rozpoznania i neutralizacji urządzeń wybuchowych.

Działania, o których mowa, można przypisać w SG do następujących komórek organizacyjnych Komendy Głównej Straży Granicznej.

Czynnościami operacyjno-rozpoznawczymi w zakresie rozpoznania zagrożeń terroryzmem i przeciwdziałania im oraz ogólną koordynacją zajmuje się Zarząd Operacyjno-Śledczy Komendy Głównej Straży Granicznej. Czynności te dotyczą m.in.:

a) bieżącej analizy sytuacji i informacji operacyjnych oraz innych uzyskanych podczas pełnienia służby granicznej dotyczących zagrożeń aktami terrorystycznymi, a także monitorowanie narażonych na te zagrożenia obszarów działalności Straży Granicznej;

b) inicjowania prac legislacyjnych, których celem jest usprawnienie metod i form rozpoznawania i zwalczania zagrożeń terrorystycznych i przeciwdziałania im, oraz opracowywanie projektów decyzji (zarządzeń) komendanta głównego Straży Granicznej;

c) ogólnego koordynowania działań antyterrorystycznych podejmowanych przez jednostki organizacyjne Straży Granicznej oraz prowadzonych w ramach współdziałania z innymi służbami (Policją, Agencją Bezpieczeństwa Wewnętrznego, Agencją Wywiadu, Wojskowymi Służbami Informacyjnymi i Żandarmerią Wojskowa);

d) sporządzania dokumentacji analitycznej, planistycznej i sprawozdawczej;

e) cudzoziemców z państw tzw. zwiększonego ryzyka, przebywających na terytorium Polski;

f) cudzoziemców podejrzanych o przekroczenie granicy państwowej wbrew przepisom, przewóz przez granicę bez zezwolenia broni, środków odurzających, psychotropowych, dużych sum pieniędzy itp.;

g) informacji uzyskanych w wyniku pracy operacyjnej SG - rozpoznanie agenturalne, procedury operacyjne, technika operacyjna;

h) informacji uzyskiwanych w toku współpracy z polskimi służbami specjalnymi, Policją, Żandarmerią Wojskową, GIIF, administracją państwową i samorządową oraz służbami granicznymi państw obcych;

i) nowych kierunków pozyskiwania informacji w wyniku udziału SG w polskich i zagranicznych specjalistycznych szkoleniach.

j) innych, niejawnych działan ${ }^{39}$.

Kontrolą radiometryczną zajmuje się Zarząd Graniczny Komendy Głównej Straży Granicznej. Za ochronę szlaków komunikacyjnych odpowiedzialne są Zarząd Graniczny

39 Z uwagi na jawną formułę pracy ograniczono się do ogólnego wskazania obszarów, w których podejmowane są czynności służbowe SG. Znakomitą większość stanowią niejawne czynności operacyjno-rozpoznawcze. 
Komendy Głównej Straży Granicznej i Sztab Komendanta Głównego Straży Granicznej. Zapobieganiem nielegalnemu przemieszczaniu przez granicę państwową materiałów wybuchowych i innych substancji niebezpiecznych, osób, pojazdów zajmują się Zarząd Graniczny Komendy Głównej Straży Granicznej i Zarząd Operacyjno-Śledczy Komendy Głównej Straży Granicznej. Zatrzymywaniem osób poszukiwanych przez organa ścigania na podstawie wpisów w bazy danych (m.in. wpisów do Systemu Informacyjnego Schengen, Ewidencji Zleceń Straży Granicznej) zajmują się Zarząd Operacyjno-Śledczy Komendy Głównej Straży Granicznej i Zarząd Graniczny Komendy Głównej Straży Granicznej. Prowadzenie zbioru dokumentów utraconych realizowane jest przez pion techniki kryminalistycznej Zarządu Operacyjno-Śledczego Komendy Głównej Straży Granicznej. Prowadzeniem profilowanego przeglądu mediów otwartych oraz polityki medialnej zajmuje się Gabinet Komendanta Głównego Straży Granicznej. Współpraca na płaszczyźnie międzynarodowej realizowana jest przez Biuro Współpracy Międzynarodowej Komendy Głównej Straży Granicznej. Prowadzeniem systemu ochronnego obiektów SG, w tym systemu przepustkowego ${ }^{40}$, zajmuje się Biuro Ochrony Informacji Niejawnych Komendy Głównej Straży Granicznej. Za realizację wart ochronnych na pokładach samolotów odpowiedzialny jest Sztab Komendanta Głównego Straży Granicznej. Prowadzeniem czynności administracyjnych wobec cudzoziemców, w tym kontrolą legalności pobytu i zatrudnienia oraz tzw. opiniowaniem wizowym, zajmuje się Zarząd do spraw Cudzoziemców Komendy Głównej Straży Granicznej.

Wskazane działania, podejmowane przez Straż Graniczna, w zakresie rozpoznawania i przeciwdziałania zagrożeniom terroryzmem, zmierzają do wszechstronności. Obejmują one nie tylko szeroko rozumiane przedsięwzięcia służbowe, w tym m.in. legislacyjne, administracyjne, operacyjne, szkoleniowe, konkretne przygotowanie do praktycznych działań na wypadek wystąpienia aktu terrorystycznego, lecz także inicjatywy niezbędne w zakresie funkcjonowania państwa, składane w ramach prac Stałej Grupy Eksperckiej przy Międzyresortowy Zespole ds. Zagrożeń Terrorystycznych. Straż Graniczna wyposażana jest w zmodernizowaną strukturę oraz nowoczesny sprzęt. Formacja, przez codzienną służbę funkcjonariuszy, zapewniła sobie silną i, jak się wydaje, stabilną pozycję w systemie ochrony interesów RP oraz jej obywateli. W ramach wciąż usprawnianego systemu antyterrorystycznego rozwija współpracę z najważniejszymi organami w państwie, służbami i instytucjami. Jest widocznym, wyróżnianym oraz sprawnym elementem w zabezpieczeniu Polski przed zagrożeniami terrorystycznymi. Straż Graniczna posiada czytelne, ustawowo umocowane rozwiązania do realizacji czynności z zakresu rozpoznawania i przeciwdziałania zagrożeniom terroryzmem oraz posiada, bliźniacze Policji, uprawnienia do stosowania wyrafinowanych metod pracy operacyjno-rozpoznawczej, takich jak m.in.: kontrolę operacyjną, przesyłkę niejawnie nadzorowaną, zakup kontrolowany, siatkę osobowych i nieosobowych źródeł

40 Choć można wskazać tu na potencjalne możliwości sprawdzania danej osoby, firmy, w różnorakich bazach danych. 
informacji, fundusz operacyjny, system analizy operacyjnej, obserwację i technikę operacyjną, operacje specjalne, z których z powodzeniem korzysta.

Jednak, pomimo wyżej wyłonionego obrazu, niezbędne jest stawianie kolejnych kroków. W najbliższej przyszłości niezbędnym jest zakończenie prac nad Narodowym Programem Antyterrorystycznym. Co równie istotne, jednym z jego zadań jest zgromadzenie wokół jednej idei, obecne stosunkowo niezależne lub niewystarczająco kompatybilne formuły działania poszczególnych służb i instytucji. Stwierdzić można, iż tylko kompleksowe stosowanie metod właściwych dla służb specjalnych i policyjnych, często równocześnie, lecz przy zapewnieniu jednolitego profesjonalnego zarządzania nimi przynosić może efekty w zwalczaniu terroryzmu. Spowodowane to jest specyfiką zjawiska, tworzeniem przez niego obszarów tak trudnych do nadzorowania, jak nazwijmy to przestępcza partyzantka miejska, nieprzewidywalna, umocowana międzynarodowo. Te cechy, wyróżniające terroryzm, są niezwykle trudne zarówno do badania, jak i do zwalczania przez pojedyncze służby. System funkcjonujący obecnie, m.in. przy wykorzystaniu Centrum Antyterrorystycznego Agencji Bezpieczeństwa Wewnętrznego, przy tak założonym środowisku działań terrorystycznych musi mieć kłopot ze sprostaniem stawianym wymaganiom. System ten, przy braku realnie odpowiedzialnego ośrodka dowodzenia informacją od początku jej uzyskania aż po czas jej potwierdzenia, w postaci procesowych zarzutów, będzie mniej skuteczny. Brakuje również systemu szkolenia funkcjonariuszy państwa, tak by mieli możliwość w sposób jednolity postrzegać zagrożenia i przy wykorzystaniu własnych ustawowych kompetencji działać efektywnie w zakresie poszczególnych służb i instytucji. To błędy, tym większe im dłużej nie są naprawiane. Jednocześnie należy przypomnieć konferencję sprzed dwóch lat, organizowaną m.in. przez ABW, pod hasłem: Czy Polsce potrzebna jest ustawa antyterrorystyczna? Dziś można by rzec - nie jest istotne, czy jest potrzebny akt rangi ustawy, niezbędna jest sprawna, kompleksowa koncepcja (np. na wzór strategii antyterrorystycznej Wielkiej Brytanii) oraz dookreślenie roli Agencji Bezpieczeństwa Wewnętrznego oraz Policji, które to służby, w ocenie autora pracy, powinny jednoznacznie wypowiedzieć się w zakresie uregulowania własnych kompetencji, właściwości, głównie w zakresie ścigania przestępstwa o charakterze terrorystycznym, dowodzenia na miejscu zdarzenia powstającego po zdarzeniu ww. typu, jak również innych działań z obszaru ochrony antyterrorystycznej kraju. Niewątpliwie pamiętać przy tym należy o roli Prokuratury, która jest panem postępowania przygotowawczego i to od niej zależą decyzje w zakresie przydzielenia danego postępowania przygotowawczego do dalszego prowadzenia. Dzisiejsze rozproszenie i niejasności interpretacyjne nie służą sprawnej pracy. Wydaje się, że powyższe może odbyć się przez uzupełnienie ustawy o ABW, np. artykułu 40(a) regulującego rzeczone kwestie, zapisów uregulowań ustawy kompetencyjnej Policji, ustawy o prokuraturze oraz tzw. Regulaminu wewnętrznego urzędowania powszechnych jednostek organizacyjnych prokuratury.

Ponadto, widocznym jest spowolnienie pracy w zakresie tworzenia założeń do tzw. ustawy antyterrorystycznej. Usprawnienie tych prac, możliwym wydaje się poprzez próbę wdrożenia ich w życie w poszczególnych ustawach kompetencyjnych, służb i instytucji zaangażowanych dotychczas w proces kształtowania założeń ww. ustawy. Następnie pakiet takich nowelizacji (ewentualnie innego rodzaju przepisów) może zostać 
skierowany na jedną, nadzorowaną przez właściwy organ (np. Międzyresortowy Zespół ds. Zagrożeń Terrorystycznych), ścieżkę legislacyjną.

Zapobieganie zjawisku terroryzmu i jego zwalczanie wymaga roztropnego i systematycznego stosowania wszelkich środków, jakie dostępne są państwu demokratycznemu. Równie istotne przy budowaniu strategii działań w tym zakresie jest odstapienie od prób idealizowania rozwiązań własnych, a pochylenie się nad możliwością implementacji założeń przyjętych w bardziej doświadczonych, w tym względzie, państwach (zapoznanych na własnym terenie z działaniami terrorystycznymi), których kolejność w zakresie sprawności wprowadzonych formuł (nie zawsze w całości możliwych do zastosowania na gruncie polskiego prawa) określić można następująco: Izrael, USA, Wielka Brytania, RFN, Francja i Rosja.

Szukając rozwiązań, możliwych do przyjęcia na polskim gruncie prawnym, w sposób naturalny należy w szczególności skupić się na rozwiązaniach przyjętych w państwach Unii Europejskiej - szczególnie ciekawą pozostaje angielska strategia Contest II oraz jej przygotowywane zmiany, co zbliży również do mariażu istniejących systemów europejskich z formuła, jaką przyjmą Polacy. Stworzenie narodowego programu antyterrorystycznego wymusi w polskiej rzeczywistości, niestety skłonnej do improwizacji, nie tylko dążenie do jednego celu, lecz także podążanie do niego jedną, zbadaną wcześniej drogą.

Na zakończenie autor pozwala sobie pozostawić czytelnika w przekonaniu, iż zamknięcie tego typu kwestii leżeć będzie wśród wielu priorytetów Straży Granicznej, która niejednokrotnie, jak dotąd, wykazywała konsekwencję w osiąganiu zamierzonych celów.

\title{
STRESZCZENIE
}

Zapobieganie zjawisku terroryzmu i jego zwalczanie wymaga efektywnego i systematycznego stosowania wszelkich środków, jakie dostępne są państwu demokratycznemu. Straż Graniczna, jako jeden z istotnych komponentów systemu antyterrorystycznego posiada czytelne, ustawowo umocowane rozwiązania do realizacji czynności z zakresu rozpoznawania i przeciwdziałania zagrożeniom terroryzmem oraz bliźniacze służbom policyjnym, uprawnienia do stosowania wyrafinowanych metod pracy operacyjno-rozpoznawczej, takich jak m.in.: kontrolę operacyjna, przesyłkę niejawnie nadzorowaną, zakup kontrolowany, siatkę osobowych i nieosobowych źródeł informacji, fundusz operacyjny, system analizy operacyjnej, obserwację i technikę operacyjna, operacje specjalne, z których z powodzeniem korzysta. Autor opisuje działania podejmowane przez Straż Graniczną w zakresie jej ustawowego zadania, polegającego na prowadzeniu czynności w zakresie rozpoznawania i przeciwdziałania zagrożeniom terroryzmem.

\section{POLISH BORDER GUARD - IDENTIFYING AND COUNTERING TERRORISM IN THE LIGHT OF POLISH AND EUROPEAN LEGISLATION}

\begin{abstract}
Preventing and combating the phenomenon of terrorism requires an effective and systematic application of all the means accessible to a democratic country. The Border Guard, as one of the
\end{abstract}


essential components of an anti-terrorist system, possesses a set of clear and legislatively established solutions for the realization of activities related to the identification and prevention of terrorist threats. The Border Guard, similar to the police service, is vested with and uses its powers to implement sophisticated methods of operational and intelligence work, such as: secret operational control, controlled delivery, controlled purchase, network of personal and non-personal sources of information, operational funds, operational analysis systems, operational surveillance and technology and special operations. The author describes the activities undertaken by the Border Guard within the scope of its statutory task, namely conducting activities as part of identifying and combating terrorist threats. 